European Journal of Accounting, Auditing and Finance Research

Vol.8, No.3, pp.69-85, March 2020

Published by $E C R T D-U K$

Print ISSN: 2053-4086(Print), Online ISSN: 2053-4094(Online)

\title{
IMPACT OF FOREIGN DIRECT INVESTMENT ON ECONOMIC DEVELOPMENT IN NIGERIA
}

\author{
${ }^{1}$ Ugwuanyi, Georgina Obinne Ph.D
}

Department of Banking and Finance, College of Management Sciences, Michael Okpara

University of Agriculture, Umudike, Nigeria.

\section{${ }^{2}$ Efanga, Udeme Okon}

Department of Banking and Finance, College of Management Sciences, Michael Okpara University of Agriculture, Umudike, Nigeria.

Email: udemeefanga@gmail.com

\section{${ }^{3}$ Ogochukwu, Chinelo Okanya Ph.D}

Department of Banking and Finance, Institute of Management and Technology, Enugu, Nigeria.

\begin{abstract}
This study was carried out to ascertain the impact of foreign direct investment on economic development in Nigeria between 1981 and 2018. Data employed for this study was elicited from World Bank Data Base-World Developmental Indicators of 2018 and Central Bank of Nigeria Statistical Bulletin of 2018. This study employed gross fixed capital formation as proxy for economic development in Nigeria, and exchange rate was employed as a controlled variable while data on foreign direct investment inflow to Nigeria was adopted as the explanatory variable. This study employed Auto Regressive Distributed Lag (ARDL) Model to analyze data; other diagnostic tests such as: stability test, Auto correlation test, Heteroskedasticity test and BreuschGodfrey Serial Correlation LM test were also carried out and they confirmed the validity and reliability of the model employed. The inferential results pointed out that foreign direct investment impacted positively but insignificantly on economic development in Nigeria between 1981 and 2018. These results also conform to apriori economic expectations. The study recommended that government of Nigeria should provide enabling environment that will be conducive for doing business, so as to attract additional inflow of foreign direct investment. Government can provide enabling business environment by provision of steady supply of electricity and ameliorating or exterminating insurgent activities in the country and restore confidence of investors to come into Nigeria and invest, when this is done, the volume of foreign direct investment into Nigeria would increase and would enhance exports thereby reducing exchange rate.
\end{abstract}

KEYWORDS: foreign direct investment, economic development, exchange rate, gross fixed capital formation and auto regressive distributed lag (ARDL) model. 
European Journal of Accounting, Auditing and Finance Research

Vol.8, No.3, pp.69-85, March 2020

Published by $E C R T D-U K$

Print ISSN: 2053-4086(Print), Online ISSN: 2053-4094(Online)

\section{INTRODUCTION}

\section{Background to the study}

All the countries in the world at all times seek ways to improve their economies either through internal business strategies and re-strategizing or external adventures. So when a country seeks outside its border for business enhancement, economic emancipation and general improvement in its finances and economy, it is referred to as foreign investment. Foreign Direct Investment (FDI) has been further described as the long term investment reflecting a lasting interest and control by a foreign direct investor or parent enterprise of an enterprise entity resident in an economy other than that of the foreign investor (IMF, 1999). Many African countries including Nigeria have reformed their economic policy, investment laws and financial system, in order to provide a conducive environment for private investment (African Economic Outlook, 2006). Sub Saharan Africa as a region has to depend heavily on FDI for many reasons, some of which are exchange of scientific research and technological collaboration (Asiedu, 2001). Foreign direct investment (FDI) has increased dramatically in the past twenty years and with an alarming increase to become the most attractive and generally accepted type of flow of capital across borders in both developed, developing and under developed economies.

According to Koojaroenprasit (2012), FDI plays a very big role in economic growth contribution via technology transfer. The increase in Capital and value addition to human capital is also associated to FDI inflows (Buckley, Clegg, Wang and Cross, 2002). In Nigeria, FDI is a business venture or a firm owned by a foreign investor or partly owned domestically.

\section{Statement of problem}

Though the market size of African countries keep growing in terms of purchasing power in the region with its vast population, political instability, internal conflict, poor governance, insecurity of life and property, and corrupt practices still pose significant problems to many countries in Africa. Nigeria's inability to attract the desired level of FDI is as a result of corruption, political, economic and social instability evidenced in pre and post election crises as well as social unrest in different parts of the country. The poor performance of the manufacturing sector in Nigeria in attracting commensurate FDI could be attributed to corruption which affect the cost of doing business in Nigeria and also hinder investors from investing in the country. Ali and Isse (2003) observed that in a country with poor economic condition, there is a tendency for such country to experience high level of corrupt practices which further worsens the rate of development. Odiaka (2006) observed that the power distribution to the industrial sector in Nigeria remains abysmally in chronic comatose. Okafor (2008) observed that the country consistently suffers from energy shortage, a major impediment to industrial, technological and economic growth. In Nigeria it is one of the many unresolved problems (Ayobolu, 2006), that have critically hobbled and skewed development.

Nigeria have been stimulating economic development with the help of various technologies including policies that would aim at foreign capital and technology transfer. It is absolutely imperative to investigate if economic development can be as a result of an increased inflow of FDI 
Vol.8, No.3, pp.69-85, March 2020

Published by ECRTD-UK

Print ISSN: 2053-4086(Print), Online ISSN: 2053-4094(Online)

into the country over the period (1981-2019). It becomes natural therefore to ask if the economic development which has been experienced in the economy for the past years was from the proceeds of foreign direct investment inflow in the country or if the country has already attained this economic development level before attracting foreign direct investment? However, with all the FDI operating in the country, the economy is still lagging behind in technology and in knowledge transfer. Due to this reason, it becomes very difficult to describe the actual direction of the relationship existing between foreign direct investment and economic development in Nigeria. It is important to carry out a research to establish the causal relationship and interaction between FDI and economic development. This however has prompted the major motivation for this study.

\section{Objectives of the Study}

The main objective of this research is to ascertain the impact of foreign direct investment on economic development in Nigeria, while the specific objectives are:

i. To examine the impact of foreign direct investment on Nigerian economic development.

ii. To investigate the impact of exchange rate on Nigerian economic development.

\section{Hypotheses of the Study}

$\mathrm{HO}_{1}$ : There is no significant impact of foreign direct investment on Nigerian economic development.

$\mathrm{HO}_{2}$ : Exchange rate does not have any significant impact on Nigerian economic development.

\section{REVIEW OF RELATED LITERATURE}

\section{Theoretical Review of Literature}

\section{Theories of Foreign Direct Investment}

\section{Macroeconomic FDI Theories}

Lipsey (2004) described the macroeconomic view as seeing FDI as a measure that aid the flow of capital across national borders measured in BOP statistics. These FDI inflows increase the stocks and capital formation of the host economy, these include the investment value in firms, corporations controlled by a home-country investor, or where a home-country investor is given a right to own a share that gives the investor the voting rights. He elucidated that interest is gotten from the financial capital inflow, the additional stock that is accumulated by the investing firms, and the flows of income from the investments. Macro-level determinants that affect the host country's ability to influence the inflow of FDI into the host country includes the size of the market, GDP growth rate, economic growth rate, good infrastructures, natural resources, institutional factors such as the political stability of the country, amongst others. The various theories are discussed below.

\section{Capital Market Theory}

This theory, also known as "currency area theory", is traced to the earliest theories which explained FDI. Based on the study of Aliber $(1970 ; 1971)$, it postulated that capital market imperfections 
Vol.8, No.3, pp.69-85, March 2020

Published by ECRTD-UK

Print ISSN: 2053-4086(Print), Online ISSN: 2053-4094(Online)

give rise to FDI. Foreign direct investment emanated from the differences between the host and the home country currencies (Nayak and Choudhury, 2014).

According to Aliber $(1970 ; 1971)$, weaker currencies have a higher FDI-attraction ability and are better able make use of the differences in the market capitalization rate, compared to stronger country currencies. Aliber $(1970 ; 1971)$, further added that source country MNCs based in hard currency areas can borrow at the rate of interest that is much lower than the host country firms because portfolio investors may not consider the foreign country MNCs currency.

This gives source country firms the easier accessibility to cheaper borrowed funds for their investment abroad and subsidiaries than what local firms would access the same funds for. While this capital market theory is applicable to developed countries including the United States, United Kingdom and Canada, other scholars saw it differently as ignoring basic currency risk management fundamentals. A major criticism of Aliber's postulation was another work by Lall (1979), when he pointed out that Aliber's theory is not applicable to the less developed countries where there is an existence of imperfect or absence of functional capital markets and to those with high foreign exchange rates regulation.

\section{Institutional FDI Fitness Theory}

As developed by Wilhems and Witter (1998), the term FDI fitness focuses on a country's potential or resources to attracting, absorbing and retaining FDI. It is a country's ability to meet up to both the internal and external expectations of its investors, which gives countries the upper-hand in harnessing FDI inflows. The theory itself made an attempt to illustrate the meaning of uneven distribution of FDI distribution between the countries concerned.

The institutional FDI fitness theory by Wilhem's is built on these fundamentals which are; Government, size of the market, educational skills and socio-cultural fitness. First on the pyramid are socio-cultural factors which according to Wilhelms and Witter (1998) are the oldest and also most complex of all institutions. The next is education, which the authors affirm to being necessary in ensuring an attractive environment for FDI as educated human capital enhances R\&D creativity and information processing ability.

The actual level of education is not the requisite for the inflow of FDI into a given region but on the essential skills needed for the projects to be undertaken. However, educational skills may affect productivity positively, effectiveness and the efficiency of FDI operations in the country it is operating. These influences from education such as the ability to speak, hear, and understand including other educational skills are keys for attracting FDI.

The third on the pyramid is the market which accounts for a large percentage of both the economic and financial aspects of institutional FDI fitness, in the form of machinery (physical capital) and credit (financial capital). Well developed and functioning financial markets are hence a prominent feature in the MNC's investment decision-making process. The fourth and very important on the pyramid is the Government. The role of a country's political strength plays the biggest role in attracting FDI. 
European Journal of Accounting, Auditing and Finance Research

Vol.8, No.3, pp.69-85, March 2020

Published by $E C R T D-U K$

Print ISSN: 2053-4086(Print), Online ISSN: 2053-4094(Online)

\section{Theory of Economic Development}

\section{Growth Theory}

The idea that economic development should naturally result in the erosion of dualism (in labor and other markets) establishes a link from classical development economics back to growth theory as pioneered by Abramovitz and Solow (1911). This, in brief, seeks to break economic growth into separable components, the most important being (a) growth in the supply of labor and capital, (b) improvements in the efficiency with which they are allocated between sectors in line with their marginal productivity, and (c) sector specific improvements in technology. Within this framework, dual economy models may be viewed as a special case that highlight one historically important set of barriers to efficient resource allocation. Empirical studies confirm that growth in low income countries is attributable more to capital accumulation, whereas in high income countries it is attributable more to technological change.

More sophisticated 'endogenous' growth models also incorporate causal links between these sources of growth, and the effect of increasing returns to scale. For example, technological change has to be embodied in capital stock and can proceed more rapidly where this is growing. The pace of technological change in different sectors is also determined by expenditure on research and human capital accumulation. Economies of scale also result from expansion of the size of markets and opportunities for specialization. But the relationship between growth and the institutions that govern resource allocation remain important. In this sense, the dual economy model is just the leading example of a range of disaggregated models that can accommodate more complex market fragmentation, and inter-sectoral rigidities. An additional important factor is the contribution to growth of natural resources. Where abundant, these help to sustain the rate of profit. But natural resources may also be a 'curse' on growth, by attracting labor and capital (and the attentions of policy makers) away from sectors with higher economies of scale and therefore longer-term growth potential.

\section{Empirical Review}

Macaulay (2012) asserted that Nigeria's foreign direct investment originated from the colonial era, in which our resources were exploited by foreign government to develop their own economy. In other to cover up their selfish ambition, they established little investment in Nigeria. But Nigeria's FDI became unstable the moment crude oil was found.John (2016), had a similar study on the effect of FDI on economic growth in Nigeria, with data sourced from CBN. He employed multiple regression technique as an analytical tool and it was seen that FDI has a positive and significant effect on GDP. Also, there was a positive but insignificant exchange rate effect on GDP.

Saibu and Keke (2014), in their paper on the impact of Foreign Private Investment (FPI) on economic growth using annual time series data from Nigerian economy, employed co-integration 
European Journal of Accounting, Auditing and Finance Research

Vol.8, No.3, pp.69-85, March 2020

Published by ECRTD-UK

Print ISSN: 2053-4086(Print), Online ISSN: 2053-4094(Online)

and Error Correction Mechanism (ECM) techniques to empirically analyze if there is any existing relationship between FPI and economic growth in Nigeria.

The paper revealed that there is a real feedback disequilibria existing between the long-run economic growth and FPI. It was also brought to the fore that a large amount of capital inflows were not productively invested, however, the left over capital that was invested, yielded a significant impact on Nigeria's economy.

The political environment was seen as unfavourable and overshadowed the significant and positive impact of FPI in Nigeria. Asogwa and Manasseh (2014), in their study revealed a positive impact on economic growth in Nigeria as a result of FDI into the manufacturing and telecommunication sectors while FDI into agricultural sector showed a negative and insignificant impact in the economy.

Eravwoke and Imide (2013), conducted a study on corruption, FDI and their impact on exchange rate of Nigerian economy. This study was centered on the empirical investigation of the impact of corruption, FDI and their impact on the exchange rate of the Nigerian economy.In an attempt to achieve the objectives of the study, OLS, augmented dickey fuller unit root tests and the cointegration test were used in the analysis. The variables were all stationary at first difference after the unit root test and corruption was seen at the extreme in Nigeria which in return depreciates the naira currency regarding its exchange value to the other currencies of the world. Nwankwo, Ademola and Kehinde, (2013), carried out a study on the impact of globalization on FDI in Nigeria. Using both descriptive and narrative method and secondary data for the analysis, the results indicated substantial benefits of FDI in Nigeria to include: the creation of employment opportunities, advancement in technology via technology transfer, encouragement of local enterprises etc. However, there are other factors that impede the full actualization of the benefits of FDI in Nigeria.

Adejumo (2013), in his study, investigated the relationship existing between FDI and the extent of the associated value-added to the manufacturing sector in Nigeria. He used ARDL model to ascertain the relationship between FDI and manufacturing value-added to the economy and in the long-run, FDI showed both negative and insignificant result. He however, argued that multinationals presence in the host economy should also influence the private investment on their economy. Likewise, these investments should not be centered in one sector but should be extended to other sectors with comparative advantage too to avoid eroding or limiting the potentials and the capabilities of the nationals. He also instructed that FPI should appreciate the effort of the host country by providing them with technical know-how, additional skills and good wages.

Solomon and Eka (2013) carried out a study on the empirical relationship between FDI and economic growth in Nigeria. The study covers from 1981-2009 and data was collated from CBN statistical bulletin. The study used OLS method to ascertain the relationship between FDI and Nigerian economic growth. From the result, FDI impacted positively but insignificantly on Nigerian economic growth. 
European Journal of Accounting, Auditing and Finance Research

Vol.8, No.3, pp.69-85, March 2020

Published by $E C R T D-U K$

Print ISSN: 2053-4086(Print), Online ISSN: 2053-4094(Online)

Okon, Augustine and Chuku (2012) from another perspective examined the feed-back relationship between FDI and economic growth in Nigeria. The method used for analysis was single and simultaneous equation systems and it was discovered that FDI and economic growth are jointly determined in Nigeria.

Egwaikhide (2012) similarly investigated the relationship between FDI and economic growth in Nigeria, using Johansen cointegration technique and VEC Method. It was noticed that the impact of the disaggregated FDI on the real growth in some sectors in Nigeria such as mining, agriculture, petroleum and manufacturing was very minute even beyond expectations but in exception of the telecommunication which shows a good sign in the long-run. Furthermore, past level of infrastructures can encourage FDI.

Omankhanlen (2011) carried out a study on the effect of FDI on the Nigerian economy covering 1980-2009. He specifically studied to ascertain if inflation and exchange rate have effect on FDI and FDI too has effect on GDP. An econometric model was developed to know the relationship between current account variables and FDI. It was discovered that FDI impacted positively and significantly on the current account balance in balance of payment. In other ways, inflation does not influence the inflows of FDI.

From another view, (Anyanwu, 2011) in his study on FDI, found the major determinants of FDI in Nigeria to include: domestic investment change, change in domestic market size, policy of indigenization and change in openness of the economy proxy as BOT. He affirmed that the abrogation of the indigenization policy in 1995 attracted more FDI inflows into Nigeria, adding that more should be done to improve the nation's economic growth so as to fascinate more FDI into the country. Unsatisfied with a narrow and short-run impact interpretation of the role of FDI, researchers have tried to incorporate other ways in which FDI influence growth in short and longrun. They do so using the framework of endogenous growth models. Whenever growth is endogenized, there are several ways in which FDI influences growth permanently.

Alejandro (2010) carried out another study on FDI and revealed the role played by FDI in the global business and economic growth. He further explained that FDI has the capacity to provide a firm with new markets and marketing channels, cheapest production facilities, provision of new technology, advancement in skills both in management and in labour application and more importantly finance for both the host country and the foreign firms. Additionally, it can provide the foreign firms with positive externalities and spillover that can foster strong economic growth. Okonkwo, Egbunike and Udeh empirically investigated the effect of foreign direct investment on Nigeria's economic growth over the period 1990 to 2012. The study made use of ordinary least squares (OLS) estimation techniques in analyzing the secondary data. The secondary data were mainly sourced from Central Bank of Nigeria statistical bulletin (CBN), Annual report and Statement of accounts. The result shows that Export assumes a positive sign which implies that there is a positive relationship between Economic growth and Export; in conclusion FDI has led to increase in Export in Nigeria. 
European Journal of Accounting, Auditing and Finance Research

Vol.8, No.3, pp.69-85, March 2020

Published by ECRTD-UK

Print ISSN: 2053-4086(Print), Online ISSN: 2053-4094(Online)

Adigwe, Ezeagba and Francis determined the relationship between foreign direct investment, exchange rate and gross domestic product. Using time series data, data for the study were collected from CBN Statistical Bulletin from 2008 to 2013. Pearson Correlation was used to test the hypothesis with aids of SPSS version 20.0. The findings revealed that there was a significant relationship between FDI, EXR and GDP, indicated that economic growth in Nigeria is directly related to foreign direct investment and exchange rate. The paper thereby recommended among others that there is need for government to be formulating investment policies that will be favorable to local investors in order to compete with the inflow of investment from foreign countries.

Tubo, Ebierinyo and Captain investigated Foreign Direct investment impact on economic growth in Nigeria using annual data for 1981 to 2016, from CBN Statistical bulletin 2016. Augmented Dickey Fuller (ADF), Johansen Co integration, Error Correction Model (ECM) and Pairwise Granger causality tests were tools of analysis. ADF result showed that all the variables [gross domestic product (GDP), foreign direct investment (FDI), Gross Fixed Capital Formation (GFCF) and exchange rate (EXR)] became stationary after differencing once. The ECM showed FDI as having positive but insignificant impact on GDP, while GFCF is positive and significant. EXR shows insignificant inverse relationship with GDP. The model speed of adjustment is about $52 \%$. There exist a one-way causality from FDI to GDP and a bi-directional causality between FDI and GFCF. Implying that building of durable world class infrastructure that boost's a country's capital sock is needed by government and private sector to enhance FDI inflow, hence economic growth. Hanson, Efanga, Ekanem and Umoh empirically evaluated Foreign Direct Investment Inflows and it's Impact on the Performance of the Nigerian Economy (1981-2017). Auto Regressive Distributed Lag (ARDL) model and Bounds Test were adopted as the estimating techniques to verify the existence of long-run relationship between foreign direct investment and economic growth of Nigeria. Real gross domestic product was used as the dependent variable, while foreign direct investment, balance of trade and exchange rate were used as the explanatory or independent variables. Data used were extracted from the Central Bank of Nigeria statistical bulletin of 2018. The empirical results of Auto Regressive Distributed Lag (ARDL) model revealed that all the variables except exchange rate had positive and significant impact on real gross domestic product. Exchange rate had a negative and insignificant impact on real gross domestic product. This study recommended that government should create an enabling environment which would attract foreign investors into Nigeria, such as good, transparent and fair tax system, promotion of economic stability and the attainment of key macroeconomic objectives.

\section{METHODOLOGY}

\section{Research Design}

This study adopts the ex-post facto research design as it deals with event that had taken place and secondary data were readily available for collection. Gross Fixed Capital Formation being a proxy for economic development was adopted as the explained variable, while Foreign Direct Investment was employed as the explanatory variable and exchange rate was used as the control variable. The model was estimated using Auto Regressive Distributed (ARDL) Model. Since we are making use of annualized time-series data and the study covers a long sample period, we made sure our data 
European Journal of Accounting, Auditing and Finance Research

Vol.8, No.3, pp.69-85, March 2020

Published by ECRTD-UK

Print ISSN: 2053-4086(Print), Online ISSN: 2053-4094(Online)

set were not impaired by unit root; hence we tested for stationarity of the series by employing the Augmented Dickey-Fuller (ADF).

\section{Sources of Data Collection}

Data for this study were extracted from World Bank Data Base- World Developmental Indicators of 2018 and Central Bank of Nigeria Statistical Bulletin of 2018. The study period covers 1981 through 2018.

\section{Method of Data Analysis}

This study employed descriptive statistics, unit root test, correlation, serial correlation test, heteroskedasticity test, normality test, stability test and Auto Regressive Distributed (ARDL) Model during the study. E-view 9.0 econometric statistical software package was used for the analysis.

\section{Model Specification}

This research adapted the economic model previously used by Hanson, et al (2020) that researched on foreign direct investment inflows and its impact on the performance of the Nigerian economy (1981-2017). The econometric model of this study, which had earlier been reviewed in the preceding section, is specified below:

$\begin{array}{lll}\mathrm{RDP}=\beta_{0}+\beta_{1} \mathrm{FDI}_{\mathrm{t}}+\beta_{2} \mathrm{EXR}_{\mathrm{t}}+\beta_{3} \mathrm{BOT}+\mathrm{u}_{\mathrm{t}} \ldots \ldots \ldots \ldots \ldots \ldots \\ \mathrm{RDP}= & \text { Real Gross Domestic Product } \\ \mathrm{FDI} & =\quad \text { Foreign Direct Investment } \\ \mathrm{EXR} & = & \text { Exchange Rate } \\ \mathrm{BOT} & = & \text { Balance of Trade } \\ \mathrm{y} & = & \text { error term } \\ \beta 0 & = & \text { Constant } \\ \beta_{1} \text { and } \beta_{2}= & \text { Coefficients of their respective variables } \\ \mathrm{t} & = & \text { Time dimension }\end{array}$

However, this study adapted the scholars' work by replacing real GDP with gross fixed capital formation as the explained variable; balance of trade was also excluded in order not to over-stock the parameters of the model; exchange rate was maintained as a controlled variable. In that regard, the regression model is specified thus:

$\mathrm{GFCF}=\beta_{0}+\beta_{1} \mathrm{FDI}+\beta_{2} \mathrm{EXR}+\varepsilon_{\mathrm{i}}$

Where; GFCF = Gross Fixed Capital Formation

$\varepsilon=$ Error term and other acronyms in the model remain as explained above.

\section{Decision Rule for Acceptance or Rejection of Hypotheses}

The decision rule is to reject the null hypothesis if the computed p-value is less than $5 \%$ significant level. On the contrary, accept the null hypothesis if the computed p-value is higher than $5 \%$ significant level.

\section{Expected Results}

Foreign Direct Investment is expected to be positively signed.

Exchange rate is expected to be negatively signed. 
European Journal of Accounting, Auditing and Finance Research

Vol.8, No.3, pp.69-85, March 2020

Published by $E C R T D-U K$

Print ISSN: 2053-4086(Print), Online ISSN: 2053-4094(Online)

\section{DATA ANALYSIS AND INTERPRETATION OF RESULTS}

Estimation Test Result (Unit Root Test)

Table 4.1 Unit Root Test

\begin{tabular}{|l|c|c|c|c|}
\hline Variables & $\begin{array}{l}\text { Augmented } \\
\text { Dickey-Fuller } \\
\text { test statistic }\end{array}$ & $\begin{array}{l}\text { Probability } \\
\text { Value }\end{array}$ & $\begin{array}{c}\text { Critical value } \\
\text { at 5\% }\end{array}$ & $\begin{array}{c}\text { Integration } \\
\text { order/Inference }\end{array}$ \\
\hline GFCF & -3.450749 & 0.0153 & -2.943427 & $\mathrm{I}(0)$ \\
\hline FDI & -7.267147 & 0.0000 & -2.945842 & $\mathrm{I}(1)$ \\
\hline EXR & -3.537770 & 0.0125 & -2.945842 & $\mathrm{I}(1)$ \\
\hline
\end{tabular}

Source: Author's analysis using e-view 9 output

The unit root test from table 4.1 above shows that the integration order of the variables were a combination of I(1) and I(0). As such, the appropriate estimation technique to employ for analysis is the Auto Regressive Distributed Lag (ARDL) Model.

Descriptive Statistics

Table 4.2 Descriptive Statistics

\begin{tabular}{|l|c|c|c|}
\hline & GFCF & FDI & EXR \\
\hline Mean & 36.47387 & 1.387343 & 104.4552 \\
\hline Median & 35.36755 & 1.384466 & 111.1675 \\
\hline Maximum & 89.38105 & 4.282088 & 306.1000 \\
\hline Minimum & 14.90391 & 0.257422 & 4.536700 \\
\hline Std. Dev. & 19.36187 & 0.855130 & 78.39935 \\
\hline Skewness & 1.009675 & 1.208768 & 0.719999 \\
\hline Kurtosis & 3.683025 & 5.208173 & 3.421495 \\
\hline Jarque-Bera & 7.195132 & 16.97413 & 3.564487 \\
\hline
\end{tabular}

\section{Source: Authors' analysis using e-view 9 output}

The result of the descriptive statistics in table 4.2 above reveals the aggregative averages such as mean, median, and the measures of spread and variation like standard deviation. Skewness which measures the degree of symmetry shows that GFCF, FDI, and EXR are positively skewed. As per the kurtosis which measures the peakedness of the observations, the values of GFCF, FDI, and EXR are above 3, hence lepturkotic. These skewness and kurtosis indicate departure from normality although such point is not strong enough to discredit the goodness of the dataset for the analysis in view.

\section{Correlation Analysis}

Table 4.3 Correlation matrix

\begin{tabular}{|c|c|c|c|}
\hline & GFCF & FDI & EXR \\
\hline GFCF & 1.000000 & & \\
\hline FDI & -0.193804 & 1.000000 & \\
\hline EXR & -0.515865 & -0.262251 & 1.000000 \\
\hline
\end{tabular}

Source: Author's analysis using e-view 9 output 
European Journal of Accounting, Auditing and Finance Research

Vol.8, No.3, pp.69-85, March 2020

Published by $E C R T D-U K$

Print ISSN: 2053-4086(Print), Online ISSN: 2053-4094(Online)

From the result of correlation analysis in table 4.3 above, both FDI and EXR variables were negatively correlated with GFCF having about $-19.4 \%$ and $-52 \%$ for FDI and EXR respectively.

\section{Inferential Result}

Results of ARDL Model

Table 4.4 Results of ARDL Model

\begin{tabular}{|lrlll|}
\hline \hline \multicolumn{1}{c}{ Variable } & Coefficient & Std. Error & t-Statistic & Prob.* \\
\hline \hline \multicolumn{1}{c}{ GFCF(-3) } & 0.337967 & 0.134391 & 2.514808 & 0.0177 \\
FDI & 1.048775 & 0.844548 & 1.241819 & 0.2243 \\
EXR & -0.027172 & 0.012206 & -2.226156 & 0.0339 \\
C & 8.419416 & 3.786140 & 2.223747 & 0.0341 \\
\hline \hline R-squared & 0.938564 & Mean dependent var & 32.42682 \\
Adjusted R-squared & 0.927971 & S.D. dependent var & 13.83630 \\
S.E. of regression & 3.713407 & Akaike info criterion & 5.616582 \\
Sum squared resid & 399.8924 & Schwarz criterion & 5.883213 \\
Log likelihood & -92.29018 & Hannan-Quinn criter. & 5.708623 \\
F-statistic & 88.60685 & Durbin-Watson stat & 1.618465 \\
Prob(F-statistic) & 0.000000 & & & \\
\hline \hline
\end{tabular}

\section{Source: Author's analysis using e-view 9 output}

The ARDL result as shown in the table above suggests that exchange rate had a negative or inverse impact on gross fixed capital formation while foreign direct investment was recorded to have a positive impact on gross fixed capital formation in Nigeria. The result further revealed that a unit increase in foreign direct investment would bring about a 1.4 unit increase in gross fixed capital formation. Also, a unit increase in exchange rate would bring about approximately 0.03 unit decrease in gross fixed capital formation and vice versa. The Adjusted R-squared of approximately 0.94 showed that the explanatory variables accounted for about $94 \%$ variations in the explained variable. Put differently, about $94 \%$ variations in gross fixed capital formation was explained by the independent variables, while the remaining $6 \%$ may be attributed to variables not included in the model.

F-statistic of 88.61 showed that the model is a good fit as confirmed by its corresponding probability value of 0.000000 which means that the model is significant both at $1 \%$ and $5 \%$ levels of significance.

Durbin-Watson stat. of 1.6 suggests that the variables are free from auto-correlation since it is very close to 2. 
European Journal of Accounting, Auditing and Finance Research

Vol.8, No.3, pp.69-85, March 2020

Published by ECRTD-UK

Print ISSN: 2053-4086(Print), Online ISSN: 2053-4094(Online)

Test for Auto Correlation

Table 4.5 Correlogram Q-Statistic

\begin{tabular}{|c|c|c|c|c|c|c|}
\hline Autocorrelation & Partial Correlation & & $\mathrm{AC}$ & PAC & Q-Stat & Prob* \\
\hline &. $\mid *$. & 1 & 0.102 & 0.102 & 0.3988 & 0.528 \\
\hline &.$\left.\right|^{*}$. & 2 & 0.160 & 0.151 & 1.4065 & 0.495 \\
\hline.$\left.\right|^{*}$ & . $*$ & 3 & 0.211 & 0.188 & 3.2048 & 0.361 \\
\hline * $*$. & * & 4 & -0.135 & -0.202 & 3.9655 & 0.411 \\
\hline .1 & .1. & 5 & 0.030 & -0.003 & 4.0043 & 0.549 \\
\hline **. & * & 6 & -0.146 & -0.153 & 4.9622 & 0.549 \\
\hline .1. &.$\left.\right|^{*}$. & 7 & 0.011 & 0.118 & 4.9677 & 0.664 \\
\hline * $*$ & * & 8 & -0.074 & -0.088 & 5.2311 & 0.733 \\
\hline$* 1$ & .1. & 9 & -0.083 & -0.010 & 5.5737 & 0.782 \\
\hline .1 &.$* 1$. & 10 & -0.033 & -0.096 & 5.6298 & 0.845 \\
\hline$*$ & $*$. & 11 & -0.163 & -0.088 & 7.0690 & 0.793 \\
\hline .1 & .1. & 12 & -0.010 & 0.002 & 7.0743 & 0.853 \\
\hline$* *$ &.$* 1$. & 13 & -0.144 & -0.093 & 8.2875 & 0.824 \\
\hline.$*$. & $* *$. & 14 & -0.160 & -0.137 & 9.8658 & 0.772 \\
\hline$\therefore$ & .1. & 15 & -0.041 & -0.040 & 9.9766 & 0.821 \\
\hline$*^{*}$ &.$* 1$. & 16 & -0.169 & -0.103 & 11.915 & 0.750 \\
\hline
\end{tabular}

Source: Author's analysis using e-view 9 output with data in Appendix

This test is carried out to further test for auto correlation and to consolidate the result of Durbin Watson Stat. The result of Correlogram Q-Statistic in table 4.5 above, suggest that the variables are free from auto correlation.

The correlogram Q- Stat. table indicates that all p-values were $>5 \%$ hence the conclusion that the model was free from auto correlation.

\section{Test for Serial Correlation}

Table 4.6 Serial Correlation

Breusch-Godfrey Serial Correlation LM Test:

\begin{tabular}{llll}
\hline \hline F-statistic & 2.486554 & Prob. F(2,27) & 0.1021 \\
Obs*R-squared & 5.443912 & Prob. Chi-Square(2) & 0.0657 \\
\hline \hline
\end{tabular}

Source: Author's analysis using e-view 9 output with data in Appendix

In line with the rules, the Breusch-Godfrey Serial Correlation LM Test table above shows that the probability values of 0.1021 and 0.0657 are statistically insignificant at $5 \%$ level of significance. That is, the p-values $(<5 \%)$ Thus, the model is said to be free from serial correlation. 
European Journal of Accounting, Auditing and Finance Research

Vol.8, No.3, pp.69-85, March 2020

Published by ECRTD-UK

Print ISSN: 2053-4086(Print), Online ISSN: 2053-4094(Online)

\section{Test for Heteroskedasticity}

Table 4.6 Test for Heteroskedasticity

Heteroskedasticity Test: Breusch-Pagan-Godfrey

\begin{tabular}{llll}
\hline \hline F-statistic & 2.526918 & Prob. F(5,29) & 0.0513 \\
Obs*R-squared & 10.62123 & Prob. Chi-Square(5) & 0.0594 \\
Scaled explained SS & 8.666760 & Prob. Chi-Square(5) & 0.1231 \\
\hline
\end{tabular}

Source: Author's analysis using e-view 9 output with data in Appendix

The Heteroskedasticity test above suggests that the variables are free from the problem of Heteroskedasticity since the p-values of F-stat. and Obs*R-squared of 0.0513 and 0.0594 respectively are $>5 \%$ significance level. This outcome is further strengthened by the p-value of the Scaled explained SS (0.1231) which also suggest the absence of Heteroskedasticity.

\section{Stability Diagnostic Test}

Table 4.8 Ramsey RESET Test

Equation: UNTITLED

Specification: (GFCF) GFCF(-1) GFCF(-2) GFCF(-3) FDI2

EXR C

Omitted Variables: Squares of fitted values

\begin{tabular}{lccc}
\hline \hline & Value & Df & Probability \\
t-statistic & 0.250670 & 28 & 0.8039 \\
F-statistic & 0.062836 & $(1,28)$ & 0.8039 \\
\hline \hline
\end{tabular}

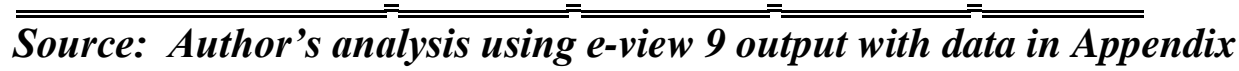

From the Ramsey reset test result in table 4.9 above, the t-statistic of 0.250670 and its corresponding p-value of 0.8039 suggest that the model is correctly specified, so null hypothesis of linear specification not rejected at $5 \%$ level of significance. That is, p-value $(<5 \%)$.

Test of Hypotheses

4.9.1 Test of Hypothesis One

\begin{tabular}{|crrrr|}
\hline \hline Variable & Coefficient & Std. Error & t-Statistic & Prob. ${ }^{*}$ \\
\hline \hline FDI & 1.048775 & 0.844548 & 1.241819 & 0.2243 \\
C & 8.419416 & 3.786140 & 2.223747 & 0.0341 \\
\hline \hline
\end{tabular}

Source: Extracted from table 4.4

$\mathrm{HO}_{1}$ : There is no significant impact of foreign direct investment on gross fixed capital formation in Nigeria. 
European Journal of Accounting, Auditing and Finance Research

Vol.8, No.3, pp.69-85, March 2020

Published by ECRTD-UK

Print ISSN: 2053-4086(Print), Online ISSN: 2053-4094(Online)

Since the p-value for foreign direct investment (FDI) of $0.2243(22.4 \%)$ is $>5 \%$ level of significance, the null hypothesis that there is no significant impact of foreign direct investment on gross fixed capital formation in Nigeria is accepted.

Test of Hypothesis Two

\begin{tabular}{|crrrr|}
\hline \hline Variable & Coefficient & Std. Error & t-Statistic & Prob. ${ }^{*}$ \\
\hline \hline EXR & -0.027172 & 0.012206 & -2.226156 & 0.0339 \\
C & 8.419416 & 3.786140 & 2.223747 & 0.0341 \\
$=$
\end{tabular}$==$

Source: Extracted from table 4.4

$\mathrm{HO}_{2}$. Exchange rate does not have any significant impact on Nigerian economic development.

Since the p-value for exchange rate (EXR) of 0.0339 (3.4\%) is within the acceptable significance level of $5 \%$, that is, $<5 \%$, we reject the null hypothesis that Exchange rate does not have any significant impact on Nigerian economic development.

\section{Apriori Economic Expectation Result}

The result is evaluated based on economic theories and literatures in line with what is obtainable in Nigeria and what is applicable all over the world.

Table 4.10 Apriori Expectation

\begin{tabular}{|l|l|l|l|}
\hline Variables & Expected Signs & Actual Signs & Remark \\
\hline FDI & Positive $(+)$ & Positive $(+)$ & Conform \\
\hline EXR & Negative $(-)$ & Negative $(-)$ & Conform \\
\hline
\end{tabular}

\section{DISCUSSION OF RESULTS}

This study was conducted to ascertain the impact of foreign direct investment on economic development in Nigeria between 1981 and 2018. From the results, it can be deduced that there exists an insignificant positive relationship between FDI and GFCF, while there exists a negative significant relationship between EXR and GFCF.

The findings of this study are in congruence with the studies of Tubo, Ebierinyo and Captain and Solomon and Eka (2013) but in negation to the studies of: Asogwa and Manasseh (2014), John (2016), Adigwe, Ezeagba and Francis and Hanson et al. (2020).

\section{CONCLUSION AND POLICY RECOMMENDATIONS}

\section{Conclusion}

The main objective of this research is to ascertain the impact of foreign direct investment on economic development in Nigeria between 1981 and 2018. This study employed gross fixed capital formation as a measure of economic development in Nigeria, while data for foreign direct 
European Journal of Accounting, Auditing and Finance Research

Vol.8, No.3, pp.69-85, March 2020

Published by $E C R T D-U K$

Print ISSN: 2053-4086(Print), Online ISSN: 2053-4094(Online)

investment into Nigeria was employed as proxy for foreign direct investment, exchange rate was employed as a controlled variable all in an attempt to ascertain the impact of foreign direct investment on economic development in Nigeria. From the inferential results, it is pertinent to submit that foreign direct investment though recorded a positive impact on economic development in Nigeria; its impact was insignificant because of the infinitesimal amount of foreign direct investment into Nigeria between the periods under review. Exchange rate recorded a negative and significant impact on gross fixed capital formation and also conforms to apriori expectations as shown in table 4.11 .

Conclusively, it will be proven statistically accurate and reliable to deduce that foreign direct investment had an insignificant impact on gross fixed capital formation in Nigeria, as such, we accept the null hypothesis that foreign direct investment had no significant impact on economic development in Nigeria.

\section{Policy Recommendations}

Based on the results of the inferential analysis above, this study proffers the following recommendation:The government of Nigeria should provide enabling environment that will be conducive for doing business, so as to attract additional inflow of foreign direct investment by fighting and reducing corruption, provision of steady supply of electricity and ameliorating or exterminating insurgent activities in the country in order to restore confidence of investors to come into Nigeria and invest. By doing that, we believe that the volume of foreign direct investments into Nigeria would increase and would enhance exports thereby improving capital formation base.. 2. The government of Nigeria should also formulate and implement favorable exchange rate policies in order to facilitate and encourage low exchange rate which would in turn become the catalyst for export and increase the purchasing power of the naira.

\section{References}

Abramovitz, M and Solow, S (1911).The theory of Economic Development. Standford University

Adejumo, A. V. (2013). Foreign direct investments and manufacturing sector performance in

Adigwe, P. K. , Ezeagba, C.E. and Udeh, F. N. P. (2015).Effect of Foreign Direct Investment on Nigerian Economic Growth. European Journal of Research and Reflection in Management Science, 3(5) 28-34.

African Economic Outlook, 2005/2006. Published by the OECD Development Centre and the African Development Bank, with financial support from the European Commission

Alejandro, D. (2010). Bautista conference foreign direct investment Mexico, United State, Canada NAFTA, presentation transcript.

Ali, A. M., \& Isse, H. S. (2002). Determinants of economic corruption: a cross-country comparison. Cato J., 22, 449. 
European Journal of Accounting, Auditing and Finance Research

Vol.8, No.3, pp.69-85, March 2020

Published by ECRTD-UK

Print ISSN: 2053-4086(Print), Online ISSN: 2053-4094(Online)

Anyawu, J. C. (2011). Foreign direct investment, export performance and sustainable development in Nigeria. Canadian centre of science and education.

Asiedu, F. (2001). "On the determinants of foreign direct investment to developing countries: Is Africa different?" World development, 30(1): 107-19

Asogwa, F. O. and Manasseh, C. O. (2014). The impact of foreign direct investment on economic growth in Nigeria. IOSR journal of economic and finance, 3(5): 37-45

Ayobolu, J. (2006). EFCC, corruption and the due process. Segun Toyin Dawodu, USA.

Buckley, P., Clegg, J., Wang, C. and Cross, A. (2002). "Foreign direct investment, regional differences and economic growth: Panel data evidence for China". Transnational Corporations. April, 11(1) 1-28.

CBN (2018). Statistical bulletin,Central bank of Nigeria.

Egwaikhide, C. I. (2012). "The impact of foreign direct investment on Nigeria's economic growth; 1980-2009: evidence from the Johansen's cointegration approach" International journal of business and social science 3(6)

Eravwoke, K. E. \& Imide, I. O. (2013). Corruption, foreign direct investment and its impact on exchange rate of the Nigerian economy. Mediterranean journal of social sciences, 4(3) Sept. 2013.

Hanson, U. Efanga, U. Ekanem, B. and Umoh, E. (2020). Foreign Direct Investment Inflows And it's Impact on the Performance of the Nigerian Economy (1981-2017) - Global Scientific Journals (GSJ),Vol. 8, Issue 2, (February, 2020) Edition - GSJ Journal Publication. ISSN: 2320 - 9186 Online.

IMF (1999). Growth in sub-Saharan Africa: Performance, impediments and policy requirements. World Economic Outlook, chapter VI., Washington, DC: IMF.

John, E. I. (2016). Effect of foreign direct investment on economic growth in Nigeria. European business and management, 2(2): 40-46

Koojaroenprasit, Sauwaluck. 2012. The impact of foreign direct investment on economic growth: A case study of

Lall, (2002). Foreign investment transactional and development countries, Macmillan Press Ltd, London.

Lipsey, R. \& Chrystal, A. (2003). Economics 10th ed. Oxford University Press. New Delhi. Developing Country Studies www.iiste.org ISSN 2224-607X (Paper) ISSN 2225-0565 (Online) Vol.5, No.9, 2015

Mody. A. and K. Srinivasan, (1998). "Japanese and United States firm as foreign investors: Do they march to the same tune?" Canadian journal of economics.31(4): 778-99.

Ngowi, H. P. (2001). Attracting new foreign direct investments to Tanzania: Tanzania Journal: 1(2): 23-39.

Nwankwo, O. G., Ademola, O. and Kehinde, O. (2013). Effects of globalization on foreign direct investment in Nigeria. Lorem journal of business and economics (LJBE) I (1)11-17.

Odiaka, P. (2006). Power Sector Reforms: Still a Reign of Blackout. The Guardian, August 24, 15.

Okafor, E.M. (2008). Development Crises of Power Supply and Implications for Industrial Sector in Nigeria. Stud Tribes Tribals, 6 (2), 83-92. 
Vol.8, No.3, pp.69-85, March 2020

Published by ECRTD-UK

Print ISSN: 2053-4086(Print), Online ISSN: 2053-4094(Online)

Okon J. U, Augustine O. J and Chuku A. C (2012). "Foreign direct investment and economic growth in Nigeria: An analysis of the endogenous effects". Current research journal of economic theory 4(3): 53-66.

Okonkwo, R. Egbunike, F. and Udeh, F. (2015). Foreign Direct Investment and Economic Growth in Nigeria, Developing Country Studies, www.iiste.org ISSN 2224-607X (Paper) ISSN 2225-0565 (Online) Vol.5, No.9, 2015

Omankhanlen. A. E. (2011). Foreign direct investment and its effect On the Nigerian economy. Perception and Rcali. The Hague: FONDAD.

Schneider, F. and B. S. Frey. (1985). "Economic and political determinants of foreign direct investment". World development, 13(2) 161-75.

Tubo, P,. Ebierinyo, A. and Captain, A.(2018). Impact of Foreign Direct Investment on Economic Growth in Nigeria, International Journal of Humanities and Social Science Volume $8 \cdot$ Number $1 \cdot$ January

Veron, R. (2006). International investment and international trade in the product cycle. Quarterly journal of economics, 4: 190-127.

Wheeler, D. and A. Mody (1992). "International investment location decisions; The case of U. S. firms", Journal of international economics (33), 57- 76.

World Bank (1996). World debt tables: External finance for developing countries.1 (analysis and summary tables). Washington D. C.

World Bank. 2019. The World Development Indicators. Available online: https://data.worldbank.org/data-catalog/ world-development-indicators (accessed on 1 March 2019). 